\title{
Analisis Kesalahan Siswa Dalam Menyelesaikan Soal pada Materi Persamaan Kuadrat
}

\author{
Grace Lisurara' Sura' $^{1, \text { a) }}$, Suradi Tahmir ${ }^{1, b)}$, dan Awi Dassa ${ }^{1, c)}$ \\ ${ }^{1}$ Jurusan Matematika, Fakultas MIPA, Universitas Negeri Makassar \\ a)gracesura@gmail.com \\ b)suradi@unm.ac.id \\ c)awi.dassa@unm.ac.id
}

\begin{abstract}
Abstrak. Penelitian ini bertujuan untuk mendeskripsikan kesalahan siswa dalam menyelesaikan soal pada materi persamaan kuadrat. Jenis penelitian ini adalah penelitian deskriptif menggunakan pendekatan kualitatif. Subjek penelitian ini adalah 3 orang siswa kelas XI SMK Negeri di Makassar yang dipilih berdasarkan banyaknya kesalahan yang dilakukan dalam menyelesaikan soal pada materi persamaan kuadrat. Adapun teknik pengumpulan data menggunakan metode tes diagnostik dan wawancara kemudian melalui tiga tahapan analisis data yaitu reduksi data, penyajian data, dan penarikan kesimpulan. Hasil penelitian diperoleh bahwa jenis kesalahan yang dialami siswa dalam menyelesaikan soal persamaan kuadrat meliputi kesalahan konsep, kesalahan prinsip, dan kesalahan perhitungan. Hal ini disebabkan karena rendahnya pengetahuan prasyarat siswa tentang operasi bilangan, siswa belum memahami tentang menentukan akar-akar persamaan kuadrat dengan cara melengkapkan bentuk kuadrat sempurna, dan siswa tidak memahami rumus abc untuk menentukan akarakar persamaan kuadrat, serta siswa kurang teliti menggunakan operasi hitung.
\end{abstract}

Kata kunci: Analisis Kesalahan, Kesalahan Konsep, Kesalahan Perhitungan, Kesalahan Prinsip, Persamaan Kuadrat

\begin{abstract}
This study aims to describe students' errors in solving questions of quadratic equation. This research type is descriptive research using qualitative approach. The subject of this research is 3 students of grade XI SMK Negeri in Makassar who were selected based on the number of errors experienced in solving questions of quadratic equation. Data collection techniques used in this study is diagnostic test and interview methods then through three stages of data analysis namely data reduction, data presentation, and conclusion. The results obtained that the types of errors experienced by students in solving quadratic equation included conceptual error, principle error, and calculation error. This was because the low of students' prerequisite knowledge about number operations, students didn't understand about finding the roots of quadratic equation by completing the perfect square, students didn't understand the abc formula to finding the roots of quadratic equation, and students inaccurate using arithmetic operations.
\end{abstract}

Keyword: Error Analysis, Concept Error, Calculation Error, Principle Error, Quadratic Equation

\section{PENDAHULUAN}

Pembelajaran matematika merupakan suatu proses belajar mengajar yang mengandung dua jenis kegiatan yang tidak terpisahkan. Kegiatan tersebut adalah belajar dan mengajar. Susanto (2013) mengatakan bahwa pembelajaran matematika adalah suatu proses belajar mengajar yang 
dibangun oleh guru untuk mengembangkan kreativitas berpikir siswa yang dapat meningkatkan kemampuan berpikir siswa, serta dapat meningkatkan kemampuan mengkonstruksi pengetahuan baru sebagai upaya meningkatkan penguasaan yang baik terhadap materi matematika.

Salah satu materi matematika yang dipelajari oleh siswa adalah persamaan kuadrat. Materi persamaan kuadrat merupakan materi yang awalnya diperkenalkan di tingkat SMP. Pada tingkat SMP, masalah yang muncul hanyalah memfaktorkan persamaan kuadrat. Menentukan penyelesaian persamaan kuadrat dan menyusun persamaan kuadrat baru akan diajarkan pada tingkat SMA/SMK.

Penyelesaian persamaan kuadrat dapat dilakukan dengan tiga cara yaitu: (1) faktorisasi, (2) melengkapkan kuadrat sempurna, dan (3) rumus abc. Hal tersebut dikuatkan dengan penelitian yang dilakukan Lima \& Tall (2010), yang menjelaskan bahwa para guru lebih memfokuskan penyelesaian persamaan kuadrat dengan menggunakan rumus abc dan sering diberikan dalam tes. Akibatnya, siswa tidak memahami dan mengalami kesulitan menyelesaikan persamaan kuadrat dengan cara faktorisasi dan melengkapkan kuadrat sempurna. Siswa kadang tidak mampu memahami penyelesaian dari $(x-2)(x-3)=0$. Zakaria \& Maat (2010), melakukan penelitian pada siswa sekolah menengah dan mengungkapkan sebagian besar siswa membuat kesalahan pada langkah transformasi dan langkah keterampilan proses. Kesalahan siswa dalam menyelesaikan persamaan kuadrat disebabkan lemahnya penguasaan materi siswa seperti aljabar, pecahan, bilangan negatif, dan ekspansi aljabar.

Beberapa kesalahan siswa pada materi persamaan kuadrat diantaranya adalah kesalahan konsep, kesalahan prinsip, dan kesalahan operasi (Manibuy, Mardiyana, \& Saputro, 2014; Nuriyah, 2015). Siswa mengalami kesulitan dalam mengidentifikasi sifat-sifat konsep yang diberikan dan mengenali kondisi yang ditentukan suatu konsep (Nuriyah, 2015). Siswa melakukan kesalahan dalam penerapan rumus dalam menjawab soal persamaan kuadrat (Manibuy, dkk, 2014). Siswa melakukan kesalahan operasi yang berkaitan dengan operasi aljabar, terutama pada operasi bilangan bulat negatif (Manibuy, dkk, 2014).

Penelitian ini berfokus pada analisis kesalahan siswa dalam menyelesaikan soal pada materi persamaan kuadrat. Tujuan penelitian ini untuk mendeskripsikan kesalahan siswa dalam menyelesaikan soal persamaan kuadrat. Subjek dalam penelitian ini adalah siswa kelas XI SMK.

\section{TINJAUAN PUSTAKA}

Masih banyak siswa yang melakukan kesalahan dalam menyelesaikan soal matematika. Menurut Munandar (2002), kesalahan didefinisikan sebagai penyimpangan terahadap hal yang benar dan sifatnya sistematis, konsisten maupun insidental pada bagian tertentu. Kesalahan yang bersifat sistematis dan konsisten dipengaruhi oleh kemampuan siswa sedang yang bersifat insidental bukan merupakan akibat rendahnya tingkat penguasaan materi pelajaran.

Jenis kesalahan yang dialami siswa bermacam-macam tergantung dari aspek mana kesalahan itu ditinjau. Menurut Cooney, Davis, \& Henderson (1975) mengatakan bahwa kesalahan-kesalahan yang dilakukan siswa dalam menyelesaikan soal matematika ditinjau dari objek matematikanya yaitu dalam memahami konsep, kesalahan dalam memahami dan menerapkan prinsip, serta kesalahan dalam melakukan algoritma. Sriati (1994), kesalahan siswa dalam mengerjakan soal matematika adalah kesalahan terjemahan, kesalahan konsep, kesalahan strategi, kesalahan sistematik dan kesalahan tanda. Sedangkan White (2005) membagi kesalahan siswa dalam menyelesaikan soal cerita matematika menjadi lima kategori kesalahan, yaitu reading errors $(\mathrm{R})$, comprehension errors $(\mathrm{C})$, transformation errors $(\mathrm{T})$, process skills errors $(\mathrm{P})$, encoding errors (E). Jenis-jenis kesalahan yang dapat terjadi pada siswa dalam menyelesaikan soal persamaan kuadrat, yaitu kesalahan konsep, kesalahan prinsip, dan kesalahan perhitungan. 


\section{Kesalahan Konsep}

Kesalahan konsep menurut Suhartin (Mursitorini, 2013) adalah kesalahan yang dilakukan oleh siswa dalam menafsirkan istilah, konsep, dan prinsip atau salah dalam menggunakan istilah, konsep, dan prinsip. Kesalahan siswa dalam memahami konsep persamaan kuadrat dapat ditinjau dari pengetahuan siswa mengenai konsep matematika sesuai dengan materi persamaan kuadrat. Berdasarkan pernyataan Conney, dkk (1975), pengetahuan siswa mengenai konsep persamaan kuadrat dapat ditinjau kemampuannya dari hal-hal sebagai berikut:

- Menandai, mengungkapkan dengan kata-kata, mendefinisikan konsep,

- Mengidentifikasi contoh dan bukan contoh dari konsep,

- Menggunakan model, gambar, dan simbol untuk mempresentasikan konsep,

- Menerjemahkan dari satu model presentasi ke model presentasi yang lain,

- Mengidentifikasi sifat-sifat konsep yang diberikan dan mengenali kondisi yang ditentukan suatu konsep, dan

- Menggunakan konsep, istilah, rumus, atau teorema untuk menjawab suatu permasalahan.

Dalam penelitian ini, indikator untuk mengetahui kesalahan konsep yang dialami siswa dalam menyelesaikan persamaan kuadrat adalah jika:

- Siswa salah dalam menentukan nilai $a, b$, dan $c$ dari suatu persamaan kuadrat,

- Siswa menambahkan kedua ruas tidak dengan $\left(\frac{b}{2}\right)^{2}$ pada persamaan kuadrat yang bentuknya telah diubah dalam $x^{2}+b x=-c$, untuk $a=1$ pada penyelesaian persamaan kuadrat dengan cara melengkapkan bentuk kuadrat sempurna.

- Siswa salah dalam menentukan rumus akar persamaan kuadrat,

- Siswa salah dalam memberikan penjelasan atas akar-akar persamaan kuadrat yang diperolehnya, atau menyelesaikan akar-akar persamaan kuadrat secara langsung dengan benar,

- Siswa salah dalam menentukan rumus jumlah dan hasil kali akar-akar persamaan kuadrat, dan

- Siswa salah dalam menentukan rumus persamaan kuadrat jika diketahui jumlah dan hasil kali akar-akar persamaan kuadrat.

- Siswa salah dalam membedakan antara bentuk umum persamaan kuadrat dan rumus $a b c$.

\section{Kesalahan Prinsip}

Kesalahan prinsip menurut Suhartin (Mursitorini, 2013) adalah kesalahan siswa dalam menyusun langkah-langkah yang hirarkis sistematis untuk menyelesaikan suatu masalah. Kesalahan siswa dalam memahami prinsip persamaan kuadrat dapat ditinjau dari pengetahuan siswa tentang prinsip-prinsip matematika yang berkaitan dengan persamaan kuadrat. Menurut Cooney, dkk (1975), pengetahuan tentang prinsip-prinsip persamaan kuadrat dapat ditinjau kemampuannya dari hal-hal berikut:

- Mengenali kapan suatu prosedur diperlukan,

- Memberikan alasan pada langkah-langkah penggunaan prosedur,

- Menggunakan prosedur secara benar,

- Mengenali prosedur yang benar dan tidak benar,

- Menggeneralisasikan prinsip baru dan memodifikasi suatu prosedur, dan

- Mengapresiasikan peran prinsip-prinsip dalam matematika.

Menurut White (2005), kesalahan prinsip merupakan tipe transformation errors yaitu siswa tidak mampu mengidentifikasi operasi atau urutan operasi yang diperlukan untuk menyelesaikan masalah dan process skills errors yaitu siswa tidak mengetahui prinsip yang diperlukan untuk melaksanakan operasi secara akurat. Pada proses penyelesaian untuk menentukan akar-akar 
persamaan kuadrat, baik dengan pemfaktoran, melengkapkan kuadrat sempurna, dan dengan rumus akar persamaan kuadrat terdapat langkah-langkah dan prinsip yang harus digunakan siswa untuk menyelesaikan masalah matematika yang berkaitan dengan persamaan kuadrat.

Dalam penelitian ini, siswa dikatakan mengalami kesalahan prinsip apabila:

- Siswa menyelesaikan persamaan kuadrat tidak sesuai dengan apa yang diinginkan dalam soal,

- Siswa melewati atau mengabaikan satu langkah penting dalam proses penyelesaian tersebut, dan

- Siswa tidak menyelesaikan soal tes diagnostik persamaan kuadrat karena tidak dapat menentukan operasi atau urutan operasi yang diperlukan.

\section{Kesalahan Perhitungan}

Kesalahan perhitungan diidentifikasi menjadi 4 kategori menurut Robert (1988) yaitu:

1. Wrong operation yaitu kesalahan penggunaan operasi hitung,

2. Obvious computational error yaitu kesalahan dalam kaidah perhitungan,

3. Defective algorithm yaitu algoritma yang tidak sempurna,

4. Random response yaitu mengerjakan dengan sembarangan.

Menurut Lerner (1995) kesalahan perhitungan dikategorikan menjadi:

1. Place value yaitu siswa melakukan kesalahan karena tidak mengerti konsep nilai tempat dan pengelompokkan,

2. Computation fact yaitu siswa melakukan kesalahan mendasar pada penjumlahan, pengurangan, perkalian, dan pembagian.

3. Using wrong process yaitu siswa melakukan kesalahan karena kurang mengenal symbol atau bentuk,

4. Working form the right to left yaitu siswa melakukan kesalahan karena kurang mengerti konsep nilai tempat.

Dalam penelitian ini, kesalahan siswa dikategorikan menjadi kesalahan perhitungan, jika siswa:

- Melakukan kesalahan dalam penggunaan operasi hitung,

- Melakukan kesalahan dalam menggunakan kaidah perhitungan, dan

- Melakukan kesalahan dasar dalam menghitung hasil penjumlahan, pengurangan, perkalian, dan pembagian.

\section{METODE PENELITIAN}

Penelitian ini menggunakan pendekatan kualitatif. Subjek dalam penelitian ini merupakan 3 orang siswa kelas XI SMK Negeri di Makassar. Penetapan subjek penelitian ini berdasarkan banyaknya kesalahan yang dialami siswa dalam menjawab soal, variasi letak kesalahan yang dialami, mampu mengemukakan pendapat terkait pertanyaan yang diberikan, dan bersedia untuk diwawancara.

Pengumpulan data penelitian dilakukan dengan metode tes dan wawancara. Metode tes yang dimaksud adalah tes diagnostik persamaan kuadrat. Tes ini bertujuan untuk mengungkap kesalahan-kesalahan siswa dalam menyelesaikan soal persamaan kuadrat. Setelah menyelesaikan soal pada tes tersebut, dilakukan wawancara sebagai alat triangulasi jawaban yang ditulis oleh subjek penelitian untuk mempelajari dan menelusuri kesalahan subjek dalam menyelesaikan soal yang diberikan. Berdasarkan metode yang dilakukan, instrumen yang digunakan pada penelitian ini berupa tes diagnostik dan pedoman wawancara yang telah divalidasi oleh dua orang ahli. Keabsahan data dilakukan dengan triangulasi metode yaitu membandingkan data yang diperoleh dari tes diagnostik dengan data yang diperoleh dari 
wawancara. Jika terdapat banyak kesamaan data yang diperoleh melalui triangulasi tersebut maka data dinyatakan valid.

Analisis data dalam penelitian ini meliputi: (1) Analisis hasil tes diagnostik persamaan kuadrat, dan (2) Analisis wawancara yang terdiri dari tiga langkah (Miles, Huberman, \& Saldana, 2014), yaitu kondensasi data, penyajian data, dan penarikan kesimpulan. Kondensasi data dalam penelitian ini meliputi penyederhanaan hasil wawancara sehingga menjadi susunan bahasa yang baik dan rapi. Kemudian menyajikan hasil wawancara dalam bentuk transkrip wawancara.

\section{HASIL DAN PEMBAHASAN}

Penelitian ini menemukan tiga jenis kesalahan yang dialami siswa dalam menyelesaikan soal persamaan kuadrat, yaitu kesalahan konsep, kesalahan prinsip, dan kesalahan perhitungan. Berikut ini merupakan penjelasan dari ketiga jenis kesalahan yang dialami oleh siswa dalam menyelesaikan soal persamaan kuadrat.

\section{Kesalahan Konsep}

Kesalahan konsep yang dialami siswa dalam menyelesaikan soal persamaan kuadrat yaitu kesalahan dalam menentukan rumus untuk menjawab soal. Kesalahan tersebut diidentifikasi sebagai berikut:

- Siswa salah dalam menuliskan rumus abc. Berdasarkan hasil pekerjaan siswa pada Gambar 1, terlihat bahwa siswa tidak menuliskan rumus $a b c$ dan siswa tidak menggunakan rumus $a b c$ untuk menentukan akar-akar persamaan kuadrat.

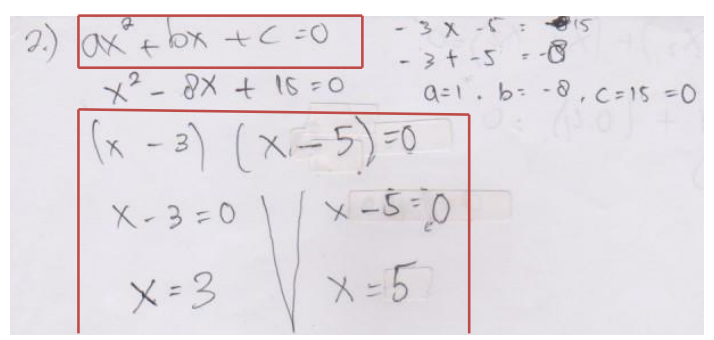

GAMBAR 1. Hasil pekerjaan siswa

Setelah dikonfirmasi melalui wawancara, ternyata siswa tidak menyadari kesalahan yang dilakukannya dalam menyelesaikan soal (Transkrip 1).

\section{TRANSKRIP 1}

$P \quad: \quad$ Cara apa yang digunakan untuk menyelesaikan soal nomor 2?

S1-18: Menggunakan rumus abc.

$P \quad:$ Bagaimana itu rumus abc?

S1-19: Yang ini rumus $a b c a x^{2}+b x+c=0$.

$P \quad$ : Yakin itu rumus abc?

S1-20: Iye.

Transkrip 1 menunjukkan bahwa siswa yakin menuliskan rumus $a b c$ yang benar yaitu $a x^{2}+$ $b x+c=0$, yang seharusnya itu merupakan bentuk umum persamaan kuadrat. Hal ini berarti siswa tidak memahami rumus $a b c$ untuk menentukan akar-akar persamaan kuadrat sehingga tidak bisa membedakan antara rumus $a b c$ dan bentuk umum persamaan kuadrat. Hasil penelitian ini sesuai dengam penelitian Manibuy, dkk (2014) yang menyimpulkan bahwa kesalahan konsep yaitu salah memahami dan menerapkan konsep rumus kuadrat pada penyelesaian soal. 
- Siswa salah dalam menuliskan bentuk persamaan kuadrat baru yang terdapat dalam soal. Berdasarkan hasil pekerjaan siswa pada Gambar 2, terlihat bahwa siswa salah dalam menuliskan bentuk persamaan kuadrat baru $x^{2}-\left(x_{1}+x_{2}\right) x+\left(x_{1} \cdot x_{2}\right)=0$.

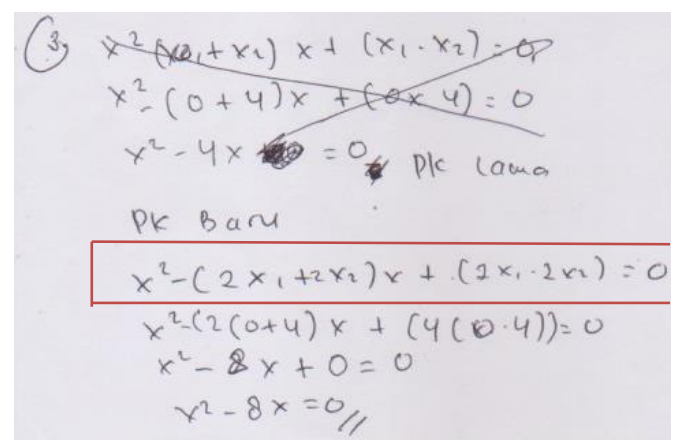

GAMBAR 2. Hasil pekerjaan siswa

Setelah dikonfirmasi melalui wawancara, ternyata siswa menyadari kesalahan yang dilakukannya dalam menyelesaikan soal (Transkrip 2).

\section{TRANSKRIP 2}

\section{$P \quad$ : Bentuk persamaan kuadrat barunya apakah sudah sesuai dengan yang diminta di soal?}

S3-22 : Oh iye salah harusnya $x_{1}+x_{2}$ dan $x_{1} \cdot x_{2}$ gak pakai 2.

Transkrip 2 menunjukkan bahwa benar siswa salah menuliskan bentuk persamaan kuadrat baru. Hasil penelitian ini sesuai dengam penelitian Manibuy, dkk (2014) yang menyimpulkan bahwa kesalahan konsep yaitu salah menerapkan konsep persamaan kuadrat baru yang diketahui akarakarnya.

Penyebab terjadinya kesalahan tersebut adalah siswa tidak memahami rumus $a b c$ untuk menentukan akar-akar persamaan kuadrat, dan siswa kurang teliti melihat bentuk persamaan kuadrat baru yang terdapat dalam soal. Hal ini sesuai dengan yang dikemukakan oleh Muzanni (2009), faktor yang menyebabkan siswa melakukan kesalahan konsep yaitu siswa kurang memiliki penguasaan konsep pada materi persamaan kuadrat dalam menentukan akar-akar persamaan kuadrat dan menyusun persamaan kuadrat baru.

\section{Kesalahan Prinsip}

Kesalahan prinsip yang dialami siswa dalam menyelesaikan soal persamaan kuadrat yaitu melewati atau mengabaikan satu langkah penting dalam proses penyelesaiannya dan kesalahan dalam menyelesaikan soal tidak sesuai dengan perintah soal. Kesalahan tersebut diidentifikasi sebagai berikut:

- Siswa tidak mengubah bentuk persamaan kuadrat menjadi kuadrat sempurna. Berdasarkan hasil pekerjaan siswa pada Gambar 3, terlihat bahwa siswa tidak menuliskan proses pengubahan persamaan kuadrat $x^{2}-5 x+4=0$ menjadi $(x-$ $\left.\frac{5}{2}\right)^{2}=\frac{9}{4}$

Setelah dikonfirmasi melalui wawancara, ternyata siswa menyadari kesalahan yang dilakukannya dalam menyelesaikan soal (Transkrip 3).

\section{TRANSKRIP 3}

$P \quad: \quad$ Coba perhatikan dari awal, apakah sudah benar atau bagaimana?

Iya kak ada yang salah. Saya tidak ubah ke bentuk $\left(x-\frac{5}{2}\right)^{2}=\frac{9}{4}$

S2-08 : karena belum paham ka cara melengkapkan bentuk kuadrat sempurna, kak. 
Transkrip 3 menunjukkan bahwa benar siswa tidak mengubah persamaan kuadrat ke bentuk kuadrat sempurna karena siswa belum paham tentang melengkapkan bentuk kuadrat sempurna. Hasil penelitian ini sesuai dengam penelitian Nuriyah (2015) dengan kesimpulan bahwa pada penguasaan prinsip, siswa paling banyak melakukan kesalahan dalam indikator tidak mengabaikan langkah penting dalam penyelesaian soal persamaan kuadrat.

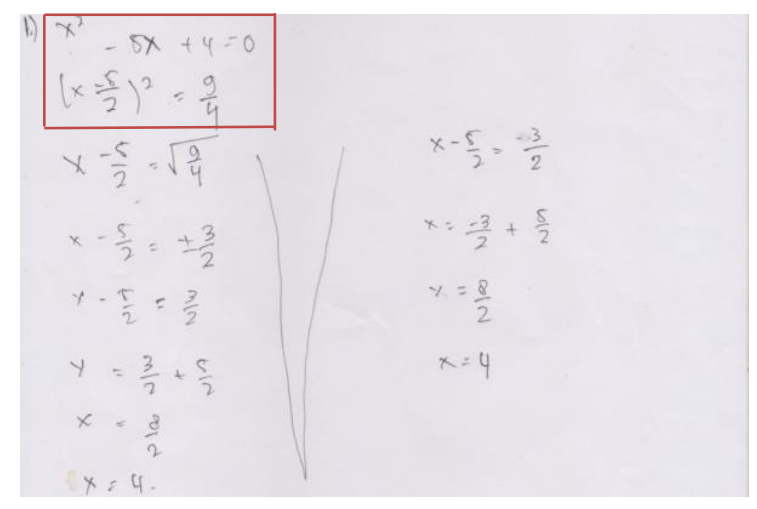

GAMBAR 3. Hasil pekerjaan siswa

- Siswa salah dalam menerapkan rumus yang sesuai dengan perintah soal yaitu selesaikan dengan menggunakan rumus $a b c$ untuk menemukan akar-akarnya. Berdasarkan hasil pekerjaan siswa pada Gambar 4, terlihat bahwa siswa tidak menuliskan rumus $a b c$ dan siswa tidak menggunakan rumus $a b c$ untuk menentukan akar-akar persamaan kuadrat.

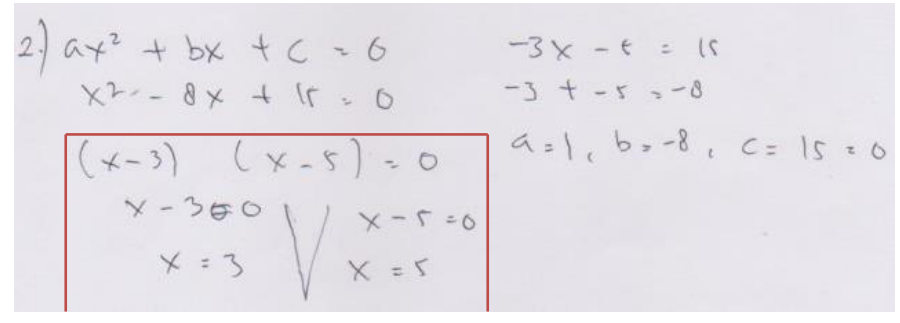

GAMBAR 4. Hasil pekerjaan siswa

Setelah dikonfirmasi melalui wawancara, ternyata siswa menyadari kesalahan yang dilakukannya dalam menyelesaikan soal (Transkrip 4).

\section{TRANSKRIP 4}

$P \quad:$ Apakah jawaban nomor 2 mu benar atau salah?

S2-15 : Iya salah kak karena tidak sama rumusnya. Beda caranya, kak. Pakai ka cara memfaktorkan karena lupa rumusnya.

Transkrip 4 menunjukkan bahwa benar siswa menggunakan cara yang berbeda dengan perintah soal karena siswa lupa rumus $a b c$. Hasil penelitian ini sesuai dengam penelitian Manibuy, dkk (2014) yang menyimpulkan bahwa kesalahan prinsip yaitu penerapan aturan dan rumus matematika yang salah dalam menjawab soal persamaan kuadrat.

Penyebab terjadinya kesalahan tersebut adalah siswa tidak dapat menentukan langkah penyelesaian soal persamaan kuadrat dengan tepat. Faktor yang menyebabkan siswa melakukan kesalahan prinsip menurut Muzanni (2009) yaitu tidak dapat menentukan langkah penyelesaian soal dengan tepat.

\section{Kesalahan Perhitungan}

Kesalahan perhitungan yang dialami siswa dalam menyelesaikan soal persamaan kuadrat yaitu kesalahan dalam melakukan operasi penjumlahan bilangan pecahan dan kesalahan dalam 
penggunaan operasi hitung. Kesalahan tersebut diidentifikasi: siswa salah dalam mencari akarakar persamaan kuadrat, seperti pada Gambar 5.

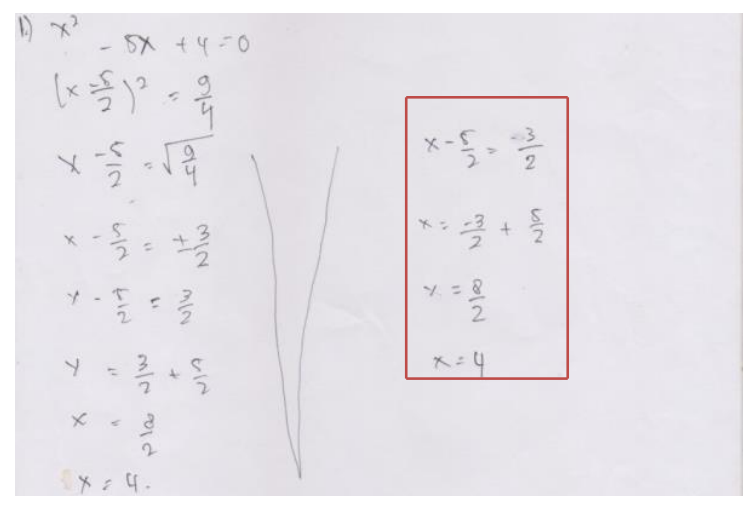

Gambar 5. Hasil pekerjaan siswa

Hasil penelitian di atas sesuai dengam penelitian Nuriyah (2015) dengan kesimpulan bahwa pada penguasaan keterampilan perhitungan, siswa mengalami kesulitan paling banyak dalam indikator terampil dalam penggunaan operasi hitung. Didukung pula oleh hasil penelitian Manibuy, dkk (2014) yang menyimpulkan bahwa kesalahan operasi yang berkaitan dengan operasi bilangan bulat negatif.

Penyebab terjadinya kesalahan tersebut adalah siswa kurang teliti di awal pengerjaannya. Faktor yang menyebabkan siswa melakukan kesalahan prinsip menurut Muzanni (2009) yaitu kurang teliti dalam melakukan hitungan.

\section{KESIMPULAN}

Jenis-jenis kesalahan yang dialami siswa dalam menyelesaikan soal persamaan kuadrat adalah (1) kesalahan konsep yang diidentifikasi: siswa salah dalam menuliskan rumus $a b c$, dan siswa salah dalam menuliskan bentuk persamaan kuadrat baru yang terdapat dalam soal. (2) kesalahan prinsip yang diidentifikasi sebagai berikut: siswa tidak mengubah soal bentuk persamaan kuadrat menjadi bentuk kuadrat sempurna, dan siswa salah dalam menerapkan rumus yang sesuai dengan perintah soal. (3) kesalahan perhitungan yang diidentifikasi: siswa salah dalam menghitung untuk mencari akar-akar persamaan kuadrat. Jenis kesalahan yang paling banyak dialami siswa dalam menyelesaikan soal persamaan kuadrat adalah kesalahan prinsip.

Faktor-faktor yang menyebabkan kesalahan yang dialami siswa dalam menyelesaikan persamaan kuadrat sebagai berikut: rendahnya pengetahuan prasyarat siswa tentang operasi bilangan, siswa belum memahami tentang menentukan akar-akar persamaan kuadrat dengan cara melengkapkan bentuk kuadrat sempurna dan siswa tidak memahami rumus abc untuk menentukan akar-akar persamaan kuadrat, serta siswa kurang teliti dalam menggunakan operasi hitung.

\section{DAFTAR PUSTAKA}

Cooney, T. J., Davis, J. E., \& Henderson, B. K. (1975). Dynamics of Teaching Secondary School Mathematics. Boston, MA: Houghton Mifflin Company.

Lerner, W. J. (1995). Learning Disabilities. Boston: Houghton M. Company.

Lima, R. N. de., \& Tall, D. (2010). An Example of the Fragility of a Procedural Approach to Solving Equations. http://homepages.warwick.ac.uk/staff/David.Tall/pdfs/dot2010x-limaquadratics-draft.pdf. diakses pada tanggal 12 Desember 2019. 
Manibuy, R., Mardiyana., \& Saputro, D. R. S. (2014). Analisis Kesalahan Siswa Dalam Menyelesaikan Soal Persamaan Kuadrat Berdasarkan Taksonomi Solo Pada Kelas X SMA Negeri 1 Plus di Kabupaten Nabire - Papua. Jurnal Elektronik Pembelajaran Matematika, 2(9). 933-945.

Miles, M. B., Huberman, A. M., \& Saldana. (2014). Qualitative Data Analysis. https://books.google.co.id/books?id=p0wXBAAAQBAJ\&printsec=frontcover\&hl=id\#v=onepag e\&q\&f=false. diakses pada tanggal 6 November 2019.

Munandar, U. (2002). Pengembangan Kreativitas Anak Berbakat. Jakarta: Rineka Cipta.

Mursitorini, M. R. A. (2013). Analisis Kesalahan Siswa dalam Menyelesaikan Soal Matematika Pokok Bahasan Peluang di Kelas XI Program IPS SMA Negeri 1 Ambarawa. (Skripsi). Universitas Negeri Yogyakarta, Yogyakarta.

Muzanni. (2009). Analisis Kesalahan Siswa Kelas X dalam Menyelesaikan Soal Matematika Pokok Bahasan Persamaan Kuadrat di SMA Negeri 1 Ambunten Sumenep. (Tesis). Universitas Muhammadiyah Malang, Malang.

Nuriyah, F. E. (2015). Analisis Kesalahan Siswa Dalam Menyelesaikan Soal Matematika Materi Pokok Persamaan dan Fungsi Kuadrat Pada Siswa Kelas X MIA SMA Negeri 2 Wonosari Tahun Ajaran 2014/2015. (Skripsi). Universitas Negeri Yogyakarta, Yogyakarta.

Robert, A. (1988). Error Patterns in Computation. New Jersey: Prentice Hall.

Sriati, A. (1994). Kesulitan Belajar Matematika pada Siswa SMA (Pengkajian Diagnosa). Jurnal Kependidikan Jogjakarta.

Susanto, A. (2013). Teori Belajar \& Pembelajaran di Sekolah Dasar. Jakarta: Prenadamedia Group.

White, A. L. (2005). Active Mathematics In Classrooms: Finding Out Why Children Make Mistakes - And Then Doing Something To Help Them. Journal of The Primary Association for Mathematics, University of Western Sydney, Square One, 15(4). 15-19

Zakaria, E. \& Maat, S. M. (2010). Analysis of Students' Error in Learning of Quadratic Equations. International Education Studies, 3(3). 105-110 